\title{
Price Transmission in the Value Chain of Hard Clam in Vietnam
}

\author{
NGUYỄN MINH ĐỨC \\ Nông Lâm University \\ nguyenminhducts@gmail.com
}

\begin{abstract}
ARTICLE INFO
Article history:

Received:

March 20, 2013

Received in revised form

Aug. 20, 2013

Accepted:

Dec. 31,2013

Keywords:

hard clam, price

transmission, time series

analysis, SUR, ECM

ABSTRACT

Using data collected from 2007-2010, this study identifies price linkages and then forecasts vertical price transmission elasticities between markets (farm, wholesale, retail and export) in the value chain of hard clam (Meratrix lyrata) in Vietnam. After doing necessary tests to make sure that all price data are stationary, Seemingly Unrelated Regression (SUR) and Error Correction Model (ECM) are employed to examine short-time and long-time effects of hard clam price in one market on the other market in its value chain. The seemingly unrelated regression results show that hard clam prices seem not depend on seasons. Farm price of hard clam is transmitted completely to wholesale price while the price in retail market causes negative effect on farm price in the short run. Wholesale price of hard clam is transmitted to both prices in farm and retail markets. The export price of hard clam is estimated not to be affected in the short run by prices in other markets except retail price in domestic markets. Error correction models confirm the independence of hard clam price on annual seasons. The transmission elasticities of prices between the markets are also identified based on model estimation.
\end{abstract}




\section{INTRODUCTION}

Fish demand is increasing in the Vietnamese domestic market, especially in HCMC. The number of supermarkets rises every year. Vietnamese people consume mostly fish (including freshwater and marine fish) in fishery structure consumption. In a recent study, most of Vietnamese consumers prefer fresh products of fish to frozen ones, especially with mollusk products.

Hard clam (Meratrix lyrata) is kept and harvested in "clam farming beaches" in coastal Vietnam. It is distributed mostly along southern coastal lines and recently migrated to coastal areas in northern and central Vietnam. With distribution areas of 10.000 - 11.500 ha, mollusk production in Vietnam is estimated at 300,000-350,000 tons a year, including 50,000-60,000 tons of hard clams. In the Mekong Delta, main production areas are in Bến Tre and Tiền Giang but also Trà Vinh, Sóc Trăng and Kiên Giang. The natural seed stock is estimated at $670-710$ tons, mostly located in Tiền Giang, Bến Tre and Trà Vinh. The clam production in Bến Tre has been awarded a MSC (Marine Stewardship Council, a British-based global certification and eco-labelling program for sustainable seafood production) certification on Nov. 9, 2009. In 2009, Vietnam exported more than 18,000 tons of hard clam, valued US $\$ 40$ million, increasing by $50 \%$ in both volume and value relative to 2008 . The EU is the biggest market of Vietnamese clam as it consumed $73.8 \%$ of export volume. The other markets include, but not limited to, the US, ASEAN, Canada, China and Hong Kong.

Sinh (2010) describes the value chain of hard clam in Vietnam in which most of hard clam output is exported to international markets (Diagram 1). The proportion of the output domestically consumed is small but increasing when hard clams are sold in every restaurant and local market. However, the price relationship among markets of the value chain is still ignored in the study in spite of the fact that price is the primary mechanism by which markets are linked, and vertical transmission of a price shock is an important element in the description of a market operation (Goodwin \& Holt, 1999). A transmission parameter summarizes the overall effect of a set of factors affecting price signals, including transaction costs that may be stationary, the existence of market power among the agents involved, the existence of non-constant returns to scale, the degree of product homogeneity, the changes of the exchange rates, and the effects of border and domestic policies (Conforti, 2004). 
This study explores the interrelationships among markets in the value chain of hard clam in Vietnam. This paper is expected to supplement the research literature on aquatic product markets in Vietnam as well as provide Vietnamese hard clam producers a tool to predict market price based on price signals from other markets in the value chain.

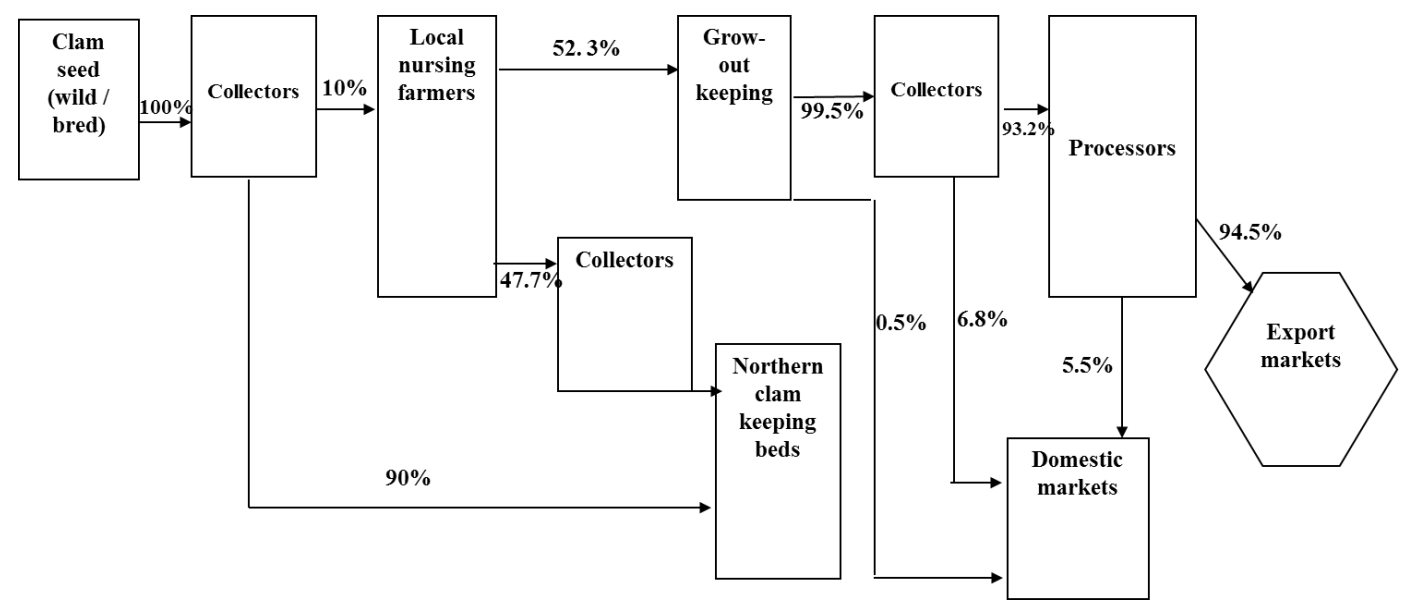

Diagram 1: The Value Chain of Hard Clam in Vietnam

Source: Sinh, 2010

\section{THEORETICAL FRAMEWORK AND RESEARCH METHODOLOGY}

\section{a. Theoretical Basis and Analysis Framework:}

A wide range of economic literature has studied the relationship between prices, either spatial or vertical. Concerning the former, a wide recent critical review is in Fackler \& Goodwin (2001). The premises of full price transmission and market integration correspond to those of the standard competition model: in a frictionless undistorted world, the Law of One Price is supposed to regulate spatial price relations, while pricing along production chains will depend exclusively on production costs, with all firms producing on the highest isoquant compatible with their isocost lines (Conforti, 2004). In a value chain of seafood (Diagram 2) summarized by Engle \& Quagrainie (2009), prices in stages of farm-gate, wholesale, retail and export markets are interrelated. Each stage in the value chain would be considered a separate market. 


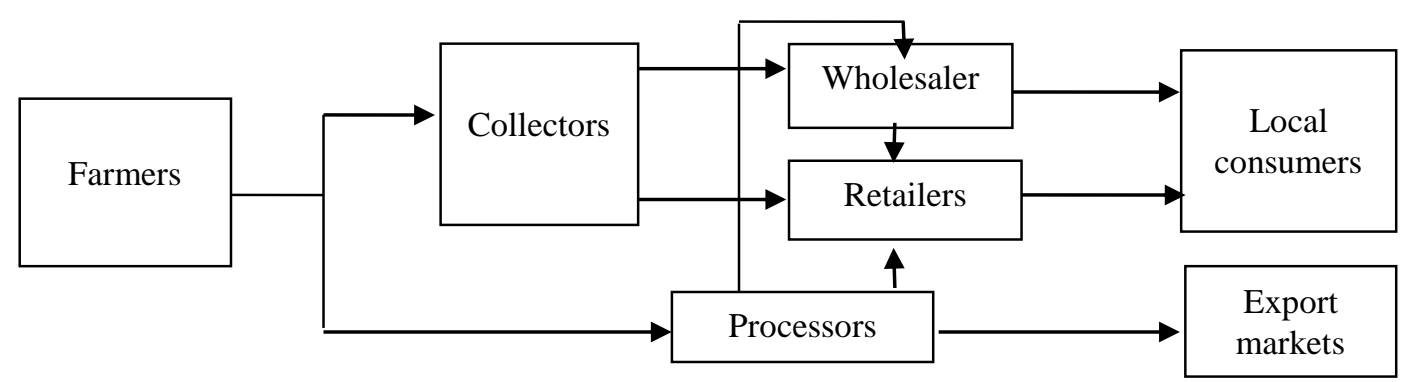

Diagram 2: Value Chain in Seafood

Source: Engle \& Quagrainie, 2009

In a value chain of a seafood (say, hard clam), an increase in demand of a market (market 1 or 2 in Figure 1) leads to a rise in its equilibrium price. The increased demand would derive an increase in demand in other markets of the chain, causing an increase in equilibrium price of the latter market (market 2 or 1). For supply side (Figure 2), due to factor-product relationship, an increase in supply of the product in a market would raise supply in other markets of the chain. These same direction increases would lead to the same direction (downward trend) change in prices in the markets. However, a change in a market may act as a signal for a change in other market (Figure 3).

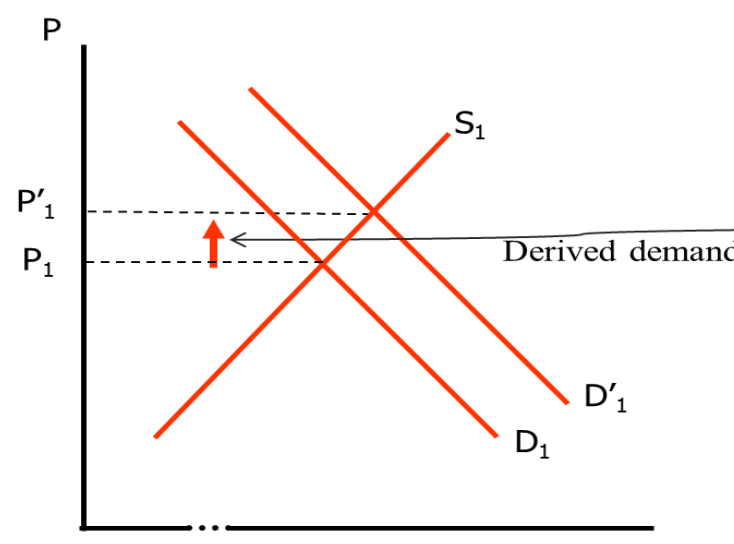

Market 1

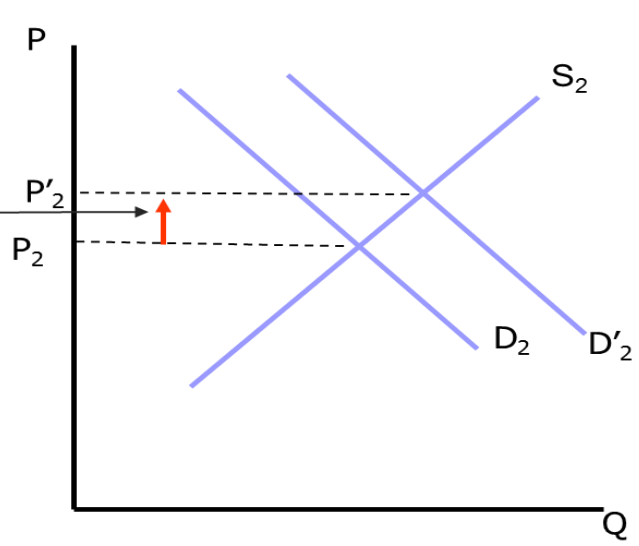

Market 2

Figure 1: Derived Demand Cause the Same Direction Change in Prices of Markets in a Value Chain 


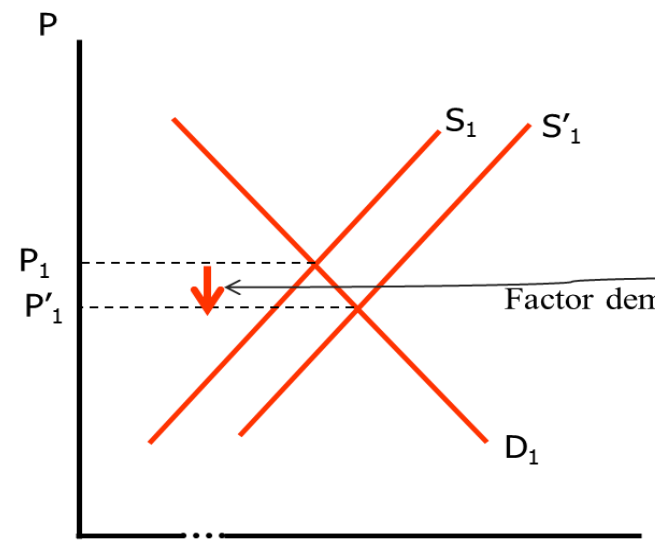

Market 1

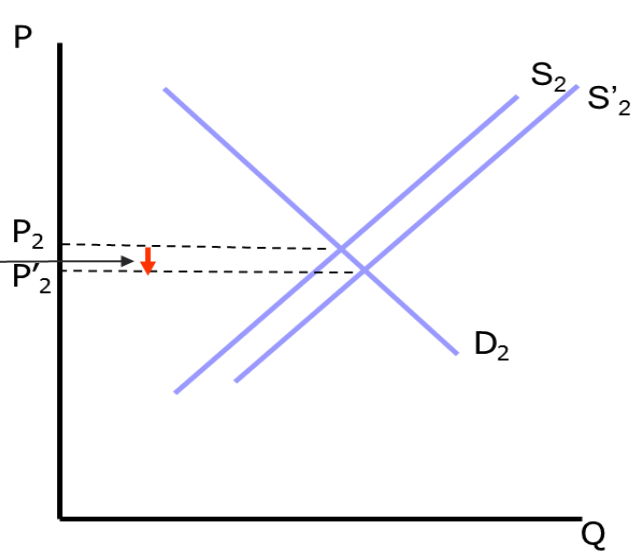

Market 2

Figure 2: A Factor-Product Relationship Causes the Same Direction Changes in Prices of Markets

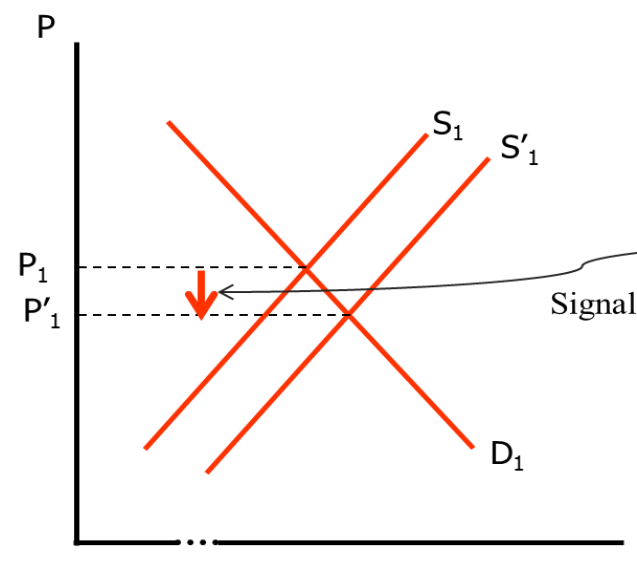

Market 1

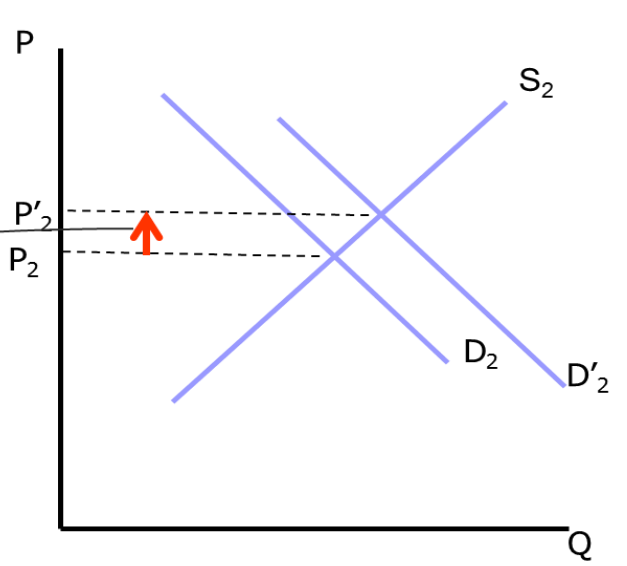

Market 2

\section{Figure 3: A Price Change in One Market is a Signal for a Price Change in Other Markets}

Using co-integration analysis for cod fish in France, Asche et al. (2002) found that prices in different markets in cod's value chain were likely to change in the same direction. They observed the cod's vessel price changed in a same trend with the ones in local and export markets. Von Cramon-Taubadel (1998) employs error correction 
models to identify linkages between pork markets in German. Giap (2010) and Duc (2010) also use this statistical method to examine price linkage between two markets: farm gate and processed channel catfish in the US. Several researches on price transmission in the value chain of channel catfish from farm to wholesale markets are implemented by various researchers such as Kinnucan \& Wineholt (1988), Gonzales et al. (2002), Nyankori (1991), Hudson \& Hanson (1999), Buguk et al. (2003), Kinnucan $\&$ Miao (1999). In Vietnam, Duc (2012) also use time series analyses to examine the effects of prices in upstream markets (wholesale, retail, and export) on price of farm gate market in the value chain of black tiger shrimp.

\section{b. Linear Regression Methods:}

Based on the above theories, this study uses linear model (Equation 1) to identify interrelationship among prices and then derive price transmission between markets of the value chain of hard clam in Vietnam with the expectation that the prices give positive effect on each other.

$$
\mathrm{P}_{\mathrm{i}}=\mathrm{f}\left(\mathrm{P}_{\mathrm{j}}, \text { res) } \quad \text { (Equation } 1\right)
$$

where $i, j=1, \ldots 4(i \neq j)$, represent four markets of farm gate, wholesale, retail price and export in the value chain of hard clams in Vietnam; res is residual of the model.

Because the double-logarithm form has been popular in economic research, for the convenience of interpreting parameters estimated, it is also employed in this study. Price of farmed fish usually fluctuates seasonally (Kinnucan \& Miao, 1999), so the dummy variables Q2, Q3, Q4 are introduced to represent quarter 1, quarter 2, quarter 3, and identify possible effects of seasons on hard clam prices in markets. Equation 1 was adjusted to Equation 2 in the form of a co integration model of hard clam.

$$
\operatorname{LnP}_{\mathrm{i}}=b_{\mathrm{i}}+\mathrm{b}_{\mathrm{j}} \ln \mathrm{P}_{\mathrm{j}}+\mathrm{Q} 2+\mathrm{Q} 3+\mathrm{Q} 4+\operatorname{res}(\text { Equation } 2) \text { with } i, j=1, \ldots 4(i \neq j) \text {. }
$$

The seemingly unrelated regression (SUR) is a generalization of a linear regression model that consists of several regression equations, each having its own dependent variable and potentially different sets of exogenous explanatory variables. The model can be estimated equation-by-equation using standard ordinary least squares. Such estimates are consistent, however generally not as efficient as the SUR method, which amounts to feasible generalized least squares with a specific form of the variancecovariance matrix. The SUR model can be viewed as either the simplification of the general linear model where certain variables are restricted to be equal to zero, or as the generalization of the general linear model where the independent variables are allowed 
to be different in each equation. The SUR model can be further generalized into the simultaneous equations regression, where the independent variables are allowed to be the endogenous variables as well.

Granger \& Newbold (1974) justify that ordinary least square (OLS), popularly used in linear regression, for time series data would not be stationary and might provide incorrect results in regression models. Von Cramon-Taubadel \& Loy (1999) develop statistical methods to correct the results based on co integration concepts by Engle \& Granger (1987) and Johansen (1988). Conforti (2004) states that co-integration between the price series analyzed implies that two prices may behave in a different way in the short run, but that they will converge toward a common behavior in the long run. If this property is verified, the characteristics of the dynamic relationship between the prices can be described by an error correction model (ECM).

Error correction models are a category of multiple time series models that directly estimate the speed at which a dependent variable returns to equilibrium after a change in an independent variable. ECMs are a theoretically-driven approach useful for estimating both short-term and long-term effects of one time series on another. Thus, they often blend well with our theories of political and social processes. ECMs are useful models when dealing with integrated data, but can also be used with stationary data.

In an ECM, the short-run adjustment parameter can be interpreted as a measure of the speed of price transmission, while the long run multiplier can be interpreted as a measure of the degree of price transmission of one price to the other (Prakash, 1999). The properties of co-integrated series also imply the existence of a causality relation, as defined by Granger, that can be tested by assessing if the past observations of one of the two prices (fail to) predict those of the other. Therefore, most analyses start by investigating the dynamic properties of the price series, through tests for the presence of unit roots, and then proceed with co-integration tests, and with the specification of ECMs.

Regarding the theory of co-integration, price interrelationships among different markets were estimated by constructing error correction models (Equation 3).

$$
d \ln \left(P_{i t}\right)=\alpha_{i}+\alpha_{i} d \ln \left(P_{j t}\right)+\text { Bres }_{i(t-1)}+u_{t} \quad \text { (Equation 3) }
$$

Where $d$ represents differences (in logarithm of prices) between the month of $t$ and $t$ $1 ; i, j=1, \ldots 4(i \neq j)$ for four markets in the value chain; $\alpha_{i}$ are elasticities representing 
price linkages between the markets; and $\beta$ is error parameter representing adjustment speed of the model toward its long-term steady state.

\section{c. Data Collection:}

Historical data, provided by Vietnam Institute of Fisheries Economics and Planning having additional reference and cross checks with market reports published by relating provincial Departments of Industry and Trading from January 2007 to December 2010, were employed for the study (Figure 4).

Farm gate prices were collected from Bến Tre and Trà Vinh Provinces - the leading production areas of hard clam in Vietnam. For domestic market, because HCMC is the largest trading center of Vietnam, wholesale prices were collected in Bình Điền Market, the biggest wholesaling center of agricultural products in HCMC and in Vietnam as well. Retail prices were from Bà Chiểu and Gò Vấp Markets which are most traditional markets in HCMC while export prices from monthly trade newsletters of Vietnam Association of Seafood Exporters and Processors (VASEP). Exchange rate data were collected from website of Asian Development Bank.

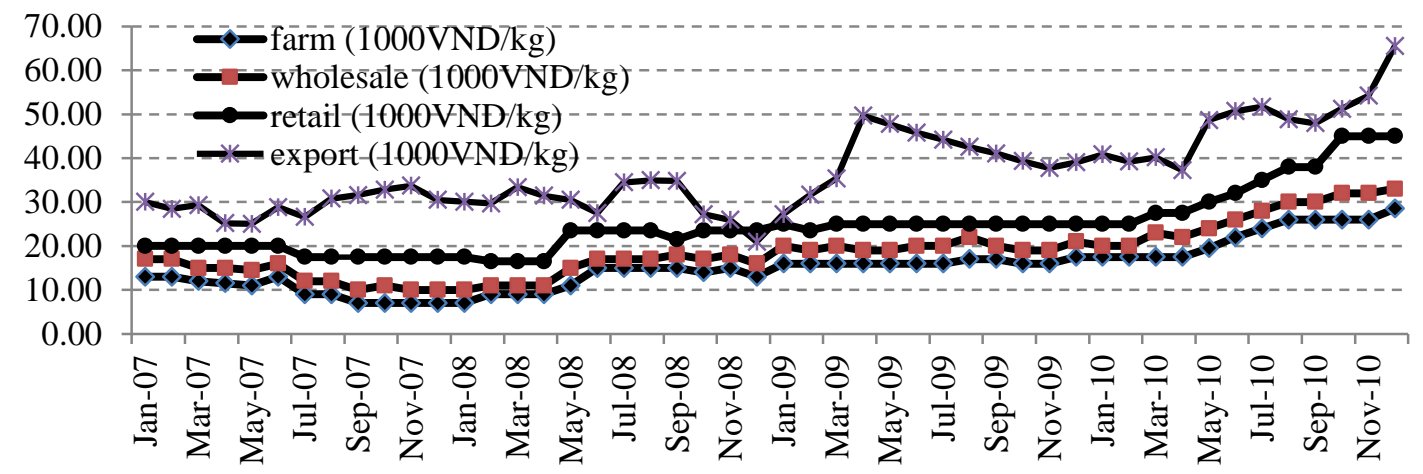

Figure 4: Price Fluctuation in Four Markets of the Hard Clam Value Chain in Vietnam

\section{RESULTS AND DISCUSSIONS}

a. Stationary in Prices of the Four Markets in the Value Chain of Hard Clams in Vietnam:

A stationary series converges to a steady state level. Price data of hard clam are not stationary and then they might be differenced-stationary. Phillips-Perron Unit Root Test 
and Augment Dickey-Fuller Test are used for unit root tests to ensure the price series are differenced-stationary.

Table 1: Unit Root Test for Clam Prices in Different Markets ( $\tau$ value)

\begin{tabular}{lcccc}
\hline & Farm-gate & Wholesale & Retail & Export \\
\hline Zero mean & 0.99 & 0.95 & 1.63 & 0.48 \\
Single mean & -0.18 & -0.15 & 0.44 & -1.2 \\
Trend & -2.49 & -2.69 & -1.86 & -2.63 \\
\hline
\end{tabular}

b. Co-integration in Prices of Four Markets in the Hard Clam's Value Chain:

Co-integration test (Table 2) confirms that price series in the markets varied in the same trend during 2007-2010. Therefore, price series can be used in double logarithm form for an OLS regression to examine the relationship between prices in different markets of the value chain of hard clam in Vietnam.

Table 2: Co-integration Test for Price Series of the Hard Clam's Value Chain in Vietnam

\begin{tabular}{ccccccc}
\hline $\begin{array}{c}\mathbf{H}_{\mathbf{0}}: \\
\text { Rank }=\mathbf{r}\end{array}$ & $\begin{array}{c}\mathbf{H}_{\mathbf{1}}: \\
\text { Rank }>\mathbf{r}\end{array}$ & Eigenvalue & Trace & Value & $\begin{array}{c}\text { Drift } \\
\text { In ECM }\end{array}$ & $\begin{array}{c}\text { Drift in } \\
\text { Process }\end{array}$ \\
\hline 0 & 0 & 0.6325 & 165.6 & 123.04 & Constant & Linear \\
1 & 1 & 0.564 & 119.55 & 93.92 & & \\
2 & 2 & 0.5169 & 81.36 & 68.68 & & \\
3 & 3 & 0.4138 & 47.9 & 47.21 & & \\
4 & 4 & 0.2942 & 23.34 & 29.38 & & \\
5 & 5 & 0.1107 & 7.31 & 15.34 & & \\
6 & 6 & 0.0407 & 1.91 & 3.84 & & \\
\hline
\end{tabular}

\section{c. Price Relationship among Four Markets in the Value Chain of Hard Clam in Vietnam:}

Difference models with variables in logarithm even regressed in single equation separately (Table 3) or in systematically (Table 4) confirm interrelationship between prices in the markets of hard clam's value chain. Positive effects of wholesale on farm gate and retail prices are confirmed as expected, but the effect of export price is not 
significant enough. However, the relationship between retail prices in domestic markets and farm gate price is negative and significant. Because most clam output in Vietnam is for export, the SUR for equation shows that farm gate price of this product affects export price. The seasonal effects are insignificant for farm gate price of hard clam in Vietnam.

d. Price Transmission between Markets in the Value Chain of Hard Clam in Vietnam:

Difference models usually represent short-term effects of explanatory variables on dependent ones. With all of residual terms of spurious models for the price series in logarithm which have passed Engle-Granger test for unite roots, ECMs can be used to explore long term relationships between the prices.

The ECMs were exhibited in Table 5.

Replacing error terms of spurious equations in to ECMs, we have double logarithm equations expressing long-term relationships between prices in various markets of hard clams in Vietnam value chain as follows:

$\ln \mathrm{P}_{1 \mathrm{t}}=0.2559+\ln \mathrm{P}_{1(\mathrm{t}-1)}+1.1327 \ln \mathrm{P}_{2 \mathrm{t}}-0.4583 \ln \mathrm{P}_{2(\mathrm{t}-1)}-0.3475 \ln \mathrm{P}_{3 \mathrm{t}}+0.3475 \ln \mathrm{P}_{3(\mathrm{t}-1)}$ $+e_{t} \quad$ (Equation 4)

$\ln \mathrm{P}_{2 \mathrm{t}}=\ln \mathrm{P}_{2(\mathrm{t}-1)}+0.6044 * \ln \mathrm{P}_{1 \mathrm{t}}-1.0247 * \ln \mathrm{P}_{1(\mathrm{t}-1)}+0.4461 * \ln \mathrm{P}_{3 \mathrm{t}}-0.6760 * \ln \mathrm{P}_{3(\mathrm{t}-1)}+\mathrm{e}_{\mathrm{t}}$ (Equation 5)

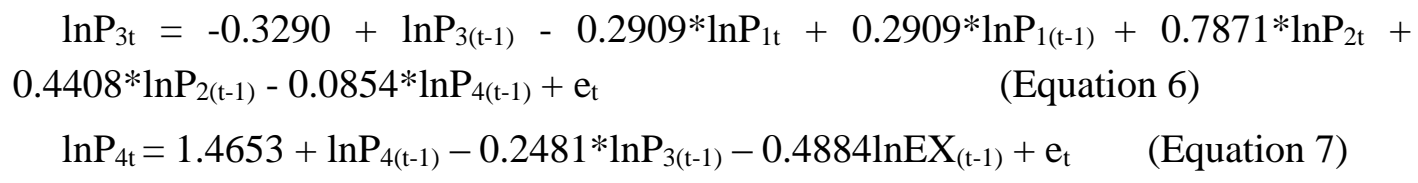

The parameters in above equations of price variables (in logarithm form) represent transmission elasticities of dependent price variable in left-hand side with respect to price repressors in right-hand side. 
Table 3: OLS Regression for Interdependence Prices in Different Markets of the Value Chain of Hard Clam in Vietnam

\begin{tabular}{|c|c|c|c|c|}
\hline & Farm & Wholesale & Retail & Export \\
\hline \multirow[t]{2}{*}{ Intercept } & 0.0062 & -0.0006 & $-9.5 \cdot 10^{-05}$ & 0.0422 \\
\hline & $(0.0183)$ & $(0.0144)$ & $(0.0178)$ & $(0.0334)$ \\
\hline \multirow[t]{2}{*}{ Farm } & & $0.6390 * * *$ & $-0.3424 * * *$ & 0.3013 \\
\hline & & $(0.0725)$ & $(0.1437)$ & $(0.2864)$ \\
\hline \multirow[t]{2}{*}{ Wholesale } & $1.0332 * * *$ & & $0.7348 * * *$ & 0.0236 \\
\hline & $(0.1172)$ & & $(0.1570)$ & $(0.3704)$ \\
\hline \multirow[t]{2}{*}{ Retail } & $-0.3629 * * *$ & $0.4816^{* * *}$ & & 0.1147 \\
\hline & $(0.1523)$ & $(0.1029)$ & & $(0.2995)$ \\
\hline \multirow[t]{2}{*}{ Export } & 0.0908 & 0.0030 & 0.0349 & \\
\hline & $(0.0861)$ & $(0.0687)$ & $(0.0847)$ & \\
\hline \multirow[t]{2}{*}{ Exchange rate } & & & & -0.3776 \\
\hline & & & & (1.8836) \\
\hline \multirow[t]{2}{*}{ Q2 } & 0.0268 & -0.0135 & 0.0337 & -0.0685 \\
\hline & $(0.0256)$ & $(0.0203)$ & $(0.0247)$ & $(0.0463)$ \\
\hline \multirow[t]{2}{*}{ Q3 } & -0.0227 & 0.0030 & -0.0060 & 0.0005 \\
\hline & $(0.0250)$ & $(0.0199)$ & $(0.0245)$ & $(0.0465)$ \\
\hline \multirow[t]{2}{*}{ Q4 } & $7.54 * 10^{-6}$ & -0.0063 & 0.0203 & -0.0703 \\
\hline & $(0.0256)$ & $(0.0201)$ & $(0.0247)$ & $(0.0457)$ \\
\hline $\mathrm{R}^{2}$ & 0.762 & 0.8123 & 0.4823 & 0.1827 \\
\hline DW & 2.261 & 2.786 & 2.537 & 1.738 \\
\hline
\end{tabular}

Notes: Figures in brackets are standard errors of parameters estimated, $* * *$ significant at $99 \%$ level 
Table 4: SUR for Interdependence Prices in Different Markets of the Value Chain of Hard Clam in Vietnam

\begin{tabular}{|c|c|c|c|c|}
\hline Variable & Farm & Wholesale & Retail & Export \\
\hline \multirow{2}{*}{ Intercept } & 0.0008 & -0.0038 & 0.002 & 0.04 \\
\hline & (0.0188) & $(0.0147)$ & $(0.0182)$ & $(0.0334)$ \\
\hline \multirow{2}{*}{ Farm } & & $0.7356 * * *$ & $-0.6343 * *$ & $0.5395^{*}$ \\
\hline & & $(0.0588)$ & $(0.1326)$ & $(0.2789)$ \\
\hline \multirow{2}{*}{ Wholesale } & $1.196382 * * *$ & & $1.0327 * * *$ & -0.2628 \\
\hline & $(0.0956)$ & & $(0.1348)$ & $(0.3632)$ \\
\hline \multirow{2}{*}{ Retail } & $-0.6769 * * *$ & $0.6776^{* * *}$ & & 0.2807 \\
\hline & $(0.1415)$ & $(0.0885)$ & & $(0.2976)$ \\
\hline \multirow{2}{*}{ Export } & $0.163974 *$ & -0.0491 & 0.08 & \\
\hline & $(0.0848)$ & $(0.0679)$ & $(0.0848)$ & \\
\hline \multirow{2}{*}{ Exchange rate } & 0.0287 & 0.1984 & -0.5344 & -0.4049 \\
\hline & $(1.0222)$ & $(0.8002)$ & $(0.9972)$ & (1.8834) \\
\hline \multirow{2}{*}{ Quarter 2} & 0.0384 & -0.0284 & 0.0387 & -0.0758 \\
\hline & $(0.0258)$ & $(0.0203)$ & $(0.0248)$ & $(0.0463)$ \\
\hline \multirow{2}{*}{ Quarter 3} & -0.0188 & 0.0129 & -0.0097 & 0.006 \\
\hline & $(0.0252)$ & (0.0199) & $(0.0248)$ & $(0.0465)$ \\
\hline \multirow{2}{*}{ Quarter 4} & 0.0137 & -0.0096 & 0.0208 & -0.0705 \\
\hline & $(0.0259)$ & $(0.0203)$ & $(0.0249)$ & $(0.0457)$ \\
\hline System $\mathrm{R}^{2}$ & \multicolumn{4}{|c|}{0.96} \\
\hline
\end{tabular}

Notes: Figures in brackets are standard errors of parameters estimated $*, * * *$ significant at $90 \%$ and $99 \%$ level respectively 
Table 5: ECMs for Prices of Hard Clam Value Chain in Vietnam

\begin{tabular}{|c|c|c|c|c|}
\hline Variable & Farm & Wholesale & Retail & Export \\
\hline \multirow[t]{2}{*}{ Intercept } & 0.0087 & -0.0016 & -0.0041 & -0.4193 \\
\hline & $(0.0160)$ & $(0.0118)$ & $(0.0166)$ & $(0.5842)$ \\
\hline \multirow[t]{2}{*}{ Farm } & & $0.6044 * * *$ & $-0.2909 * * *$ & 0.2711 \\
\hline & & $(0.0599)$ & $(0.1349)$ & $(0.2619)$ \\
\hline \multirow[t]{2}{*}{ Wholesale } & $1.1327 * * *$ & & $0.7871 * * *$ & -0.1280 \\
\hline & $(0.1059)$ & & $(0.1471)$ & $(0.3404)$ \\
\hline \multirow[t]{2}{*}{ Retail } & $-0.3475^{* * * *}$ & $0.4461 * * *$ & & 0.2236 \\
\hline & $(0.1331)$ & $(0.0847)$ & & $(0.2801)$ \\
\hline \multirow[t]{2}{*}{ Export } & 0.0372 & 0.0143 & 0.0700 & \\
\hline & $(0.0767)$ & $(0.0564)$ & $(0.0797)$ & \\
\hline \multirow[t]{2}{*}{ Exchange rate } & & & & 0.1583 \\
\hline & & & & $(0.2075)$ \\
\hline \multirow[t]{2}{*}{ Q2 } & 0.0138 & -0.0061 & 0.0317 & -0.0510 \\
\hline & $(0.0227)$ & $(0.0167)$ & $(0.0229)$ & $(0.0426)$ \\
\hline \multirow[t]{2}{*}{ Q3 } & -0.0180 & 0.0011 & -0.0009 & 0.0095 \\
\hline & $(0.0219)$ & $(0.0163)$ & $(0.0229)$ & $(0.0434)$ \\
\hline \multirow[t]{2}{*}{ Q4 } & -0.0068 & -0.0023 & 0.0240 & -0.0598 \\
\hline & $(0.0225)$ & $(0.0165)$ & $(0.0230)$ & $(0.0428)$ \\
\hline \multirow[t]{2}{*}{ Lagresspur } & $-0.5386 * * *$ & $-0.6584 * * *$ & $-0.3811 * * *$ & $-0.3832 * * *$ \\
\hline & $(0.1471)$ & $(0.1453)$ & $(0.1407)$ & $(0.1386)$ \\
\hline $\mathrm{R}^{2}$ & 0.82 & 0.88 & 0.56 & 0.34 \\
\hline D.W. & 1.7 & 2.2 & 2.1 & 1.7 \\
\hline
\end{tabular}

Notes: Figures in brackets are standard errors of parameters estimated *** significant at $99 \%$ level

\section{e. Discussion:}


With the above long-term equations estimated, the transmission elasticity of farm price in respect of wholesale price is 1.13, exhibiting a powerful impact of wholesale market on farm price of hard clam. This impact makes the farm gate price very sensitive to wholesale price. When the price in the wholesale market increases by $1 \%$, farm price would increase more than $1 \%$, by $1.13 \%$. The price transmission elasticity of hard clam farm price to retail price is -0.35 in one-month periods. This result shows an increase in retail market of hard clam may be a signal for a decrease in farm price caused by a possible increase in farmed hard clam harvest to response the increase in domestic retail markets as represented in Figure 3. Farm price is adjusted positively in the long run following the one-month lag of retail price, representing a derived demand relationship (Figure 1). However, farm price adjusted negatively following the one-month lag of wholesale price in long run, exhibiting a factor-product relationship as in Figure 2.

The transmission elasticity of wholesale price in respect of farm price is 0.60 and to retail price is 0.44 . This result confirms that farm price is transmitted positively to wholesale price of hard clam although wholesale price is adjusted negatively by both farm and retail prices in previous months.

The transmission elasticity of retail price in respect of farm price is -0.29 , exhibiting a positive interrelationship between retail and farm prices. When all markets are adjusted in the long run, farm price and retail price do not affect each other with zero parameter summation (for 2 periods) of retail price in Equation 4 and of farm price in Equation 6. The transmission elasticity of retail price in respect of wholesale price being 0.79 also shows a positive interrelationship between retail and wholesale prices. This result once again confirms the power of wholesale markets (dominated by middlepersons) on prices of both farm and retail markets. The negative relationship between export and retail prices in previous months suggests that the two markets are competing for the product and a change in export price may act as a signal for a change in price of retail market.

Export price of hard clam is not affected by prices in other markets, except retail one, in its value chain in short run. This result reveals that export price of hard clam seems to be independent in short time with respect to domestic markets fluctuation. Vietnam is still a small exporter of hard clam, so that it is a price taker, in the global market. Price fluctuation in domestic markets is not strong enough to give a significant influence on export price. However, export price is affected negatively by exchange rate in previous months. As Vietnamese currency loses its value, export price of hard clam is estimated 
to be lower, resulting in a possible increase in export volume to international markets. This result is consistent with trade theory in international economics.

\section{CONCLUSIONS AND POLICY IMPLICATIONS}

\section{a. Conclusions:}

The linear regression results shows that hard clam prices seem independent from seasons. Farm price is transmitted completely to wholesale price while the price in retail market produces negative effect on farm price in the short run. Wholesale price has been transmitted to both prices in farm and retail markets. The regression for the export price shows that the price seems not to be affected in the short run by prices in wholesale and retail markets but receiving a positive effect from farm price. Error correction models confirm the independence of hard clam price on annual seasons. The ECM results confirm price transmission from farm to wholesale market and from the down-stream markets to retail one in the value chain. Negative effect of USD-VND exchange rate on hard clam export price is also estimated by the models.

\section{b. Policy Implications:}

The findings from this study supplement recent researches in Vietnamese fishery sector and create a potential empirical base for future researches on other aquatic products. Price fluctuation, a reason of bullwhip effect in supply chain, is not only important to economists but also to corporate managers, especially in agri-business industry. The results from this study justify that for the long run, prices in markets of clam value chain have adjusted according to not only their lags but also signs of price fluctuation in other markets. Upstream corporates (retailers and exporters) can forecast future prices in other markets of the value chain based on previous price data changes in domestic markets.

In this study wholesale price of hard clam is confirmed to be transmitted to both prices in farm and retail markets, exhibiting the critical role and power of middlemen in market price decision. To support stability of this value chain, market controlling officials should take measures to supervise the power of those key market players.

The findings are also expected to provide clam producers with knowledge of price signals from wholesale and export markets. With better communication through available telephone and the Internet, clam farmers would find previous market price data and forecast the changes in farm price to help them in production planning and empower them in trading negotiation with middlemen and processing companies 


\section{References}

Asche, F. et al. (2002), "Vertical Relationships in the Value Chain: An Analysis Based on Price Information for Cod and Salmon in Europe", Working Paper, SNF Project Report No. 5310, Centre for Fisheries Economics, Institute for Research in Economics and Business Administration, Bergen, Norway.

Buguk, C., D. Hudson \& T. Hanson (2003), "Price Volatility Spillover in Agriculture Market: An Examination of U.S. Catfish Market", Journal of Agricultural and Resource Economics 28(2003):86-99.

Conforti, P. (2004), "Price Transmission in Selected Agricultural Markets", FAO Commodity and Trade Policy Research Working Paper No. 7

Duc, N.M. (2010), “Application of Econometric Models for Price Impact Assessment of Antidumping Measures and Labelling Laws on Global Markets: A Case Study of Vietnamese Striped Catfish", Reviews in Aquaculture, 2(2):86-101.

Duc, N.M. (2012), "Effects of Domestic And Export Prices on Farm Price - An Econometric Analysis for Black Tiger Shrimp”, Journal of Science, HCMC Open University 2012(5)

Engle R.F. \& C.W.J. Granger (1987), "Co-integration and Error Correction: Representation, Estimation and Testing”, Econometrica 55(2): 251-276.

Engle, C. \& K. Quagrainie (2009), Aquaculture Marketing Handbook. Wiley-Blackwell Publishing Inc. 288pp.

Giap, N.V. (2010), "Supply Response, Price Transmission, and Risk in the U.S. Catfish Industry", PhD Dissertation. Auburn University.

Granger, C. \& P. Newbold (1974), "Spurious Regression in Econometrics", Journal of Econometrics, 2: 111-120.

Gonzales, F., P. Guillotreau \& L. Le Grel (2002), “The Transmission of Price Variability along the French Cod Value Chain”, XIVth EAFE Conference, Faro, 25-27 March 2002

Goodwin, B.K. \& M.T. Holt (1999), "Price Transmission and Asymmetric Adjustment in the U.S. Beef Sector," American Journal of Agricultural Economics, 81(3): 630-637

Hudson, D. \& T. Hanson (1999), “An Examination of Farm/Processor Price Spreads in Catfish Markets”, Aquaculture Economics and Management 3:222-228.

Johansen, S. (1988), "Statistical Analysis of Cointegration Vectors", Journal of Economic Dynamics and Control, 12(2-3): 231-254.

Kinnucan H.W. \& Y. Miao (1999), "Media-Specific Returns to Generic Advertising: The Case of Catfish", Agribusiness 15(1):81-99. 
Kinnucan, H.W. \& D. Wineholt (1989), Processor Demand and Price Mark-up Function for Catfish at the Processor Level, Bulletin 597, Alabama Agricultural Experiment Station, Auburn University, Auburn, AL.

Nyankori, J. C. O. (1991), "Price Transmission in the Catfish Industry with Specific Emphasis on the Role of Processing Cooperatives", Southern Journal of Agricultural Economics 23:247-252.

Sinh, L. X., (2010), “A Study for Solutions for Production and Business of Hard Clam (Meretrix lyrata) in Southern Coastal Provinces", Cần Thơ University, Research code: B2009-16-142

Von Cramon-Taubadel, S. (1998), Estimating Asymmetric Price Transmission with the Error Correction Representation: An Application to the German Pork Market", European Reviews of Agricultural Economics 25: 1-18.

Von Cramon-Taubadel, S.. \& J.P. Loy (1999), “The Identification of Asymmetric Price Transmission Processes with Integrated Time Series”, Jahrbücher für Nationalökonomie und Statistik 218(1-2): 85-106. 